\title{
Game preferences of K-12 level students: analysis and prediction using the association rule
}

Zeynep Cömert, Bahçeşehir University, Office of Distance Education, zeynep.comert@de.bau.edu.tr, ORCID: 0000-0002-1841-4194

Ergün Akgün, Bahçeşehir University, Faculty of Educational Sciences, ergun.akgun@de.bau.edu.tr, ORCID: 0000-0002-7271-6900

\begin{abstract}
Many different tools have accompanied the self-realization processes of human beings such as love, belonging, respect, socialization and gaining new experiences. These tools have differentiated depending on the development in science and technology or have been replaced by new tools. Games, on the other hand, have been constantly renewed by this process and have survived until today and have become an important industry today. In addition, games have become a frequent part of learning environment designs recently. Accordingly, the need for outstanding educational game designs has increased. Many game design models have been introduced to guide educational game designs for this need. However, following these models does not guarantee that the games provide an enjoyable learning experience. Therefore, a roadmap is needed for the design process as well as models. In line with this stated need, the game preferences of the students were examined within the scope of the research. After the examinations, a roadmap was presented based on the similarities and differences of students' game preferences.
\end{abstract}

Keywords: Cambria, 10 font, Between 3 to 7 words, 1st word's initial should be capital

Received: 05.05.2020

Accepted: 05.08.2020

Published: 01.12 .2020

\section{INTRODUCTION}

Throughout history, human beings have made use of many tools as a mean to self-actualization needs such as love, commitment, showing/receiving respect, socializing, and pursuing new experiences. These tools have differed through time from the very primitive act of hunting to drawing on cave walls, watching a performance being staged in a theater, or posting something on social media. Some of these tools have long disappeared while some still survive. For example, games have become tradition through a long history of cultural reproduction. According to Huizinga (1938). Games were present long before humans created cultures, as a simple observation of the kind of communication animals establish among themselves reveals. Thus, it is possible to state that games are one of the oldest activities that serve the individual's selfactualization process.

On the other hand, over time, the characteristics of all the various means and activities that serve this self-actualization process have also changed. The main reason why games, dating back much longer than human culture, still prevail as one of these tools is that they can keep up with these changes. In other words, the fact that games can take many forms in the face of changing audiences, needs, and contexts may influence their everlasting presence. Over time, games have been carried from the street to different platforms, where they have now become richer in design. Not only did this transition lead to a boost in the diversity and accessibility of games, but also to some changes in the profiles of the players.

With that said, it would not be appropriate to assume that games are only processes or tools to be used in the self-actualization of individuals. Games are also considered to be one of the oldest learning technologies ever known (Crawford, 1984). Educational specialists who wish to design effective learning experiences often make use of games in learning environments. In these environments, educational specialists can follow various strategies while integrating games into the learning process. These strategies are: (1) integrating the learning content into the existing games that students play, (2) teaching an authentic game which matches the learning content, or (3) letting the students design that game (van Eck, 2006). 
The results of various studies indicate that when these strategies are pursued in the design process, learning environments have a supporting effect on students in terms of their academic achievement (Barzilai \& Blau, 2014; Sung \& Hwang, 2013; Tsai, Huang, Hou, Hsu \& Chiou, 2016; Tüzün, Yılmaz-Soylu, Karakuş, İnal \& Kızılkaya, 2009), motivation level (Burguillo, 2010; Erhel \& Jamet, 2013), spatial ability (Yıldız \& Tüzün, 2011) and creative thinking skills (Bulut, 2015). It stands to reason that just like any other learning environment, the design of educational games also requires effective planning and process analysis, a concern for educational design principles, and the use of game design models. Many models for game design are available that provide such guidelines for game developers (Akıllı \& Çă̆ıltay, 2006; Amory, 2007; Kiili, 2005; Song \& Zhang, 2008; Zin, Jaafer \& Yue, 2009). For example; Kiili (2005) emphasized that educational game design must be progressed by associating with Vygotsky's zone of proximal development while determining challenges and goals at a difficulty appropriate to the player's level. Similarly, Moreno-Ger, Burgos, Martínez-Ortiz, Sierra and Fernández-Manjón (2008) stresses that measurement and evaluation theory should be taken as a basis in education while designing a feedback system within the game. Therefore, educational game design is defined as a field where game design and educational theories meet to trigger or support learning (Dodlinger, 2007; Stalfuinen \& Freitas, 2011). Due to all this situation, many educational game design models have been developed. However, completing the process by following an appropriate design model does not guarantee successful design results.

Many educational games are critized and liken chocolate covered broccoli, because of lacking both entertainment and educational elements (Bruckamn, 1999). In order to avoid these criticisms, it is suggested that educational games should be designed in a way similar to serious games that require the person to play constantly and make an effort to succeed (Annetta, 2010). For this reason, serious game preferences that people play in daily life contain important clues (Annetta, 2010; Stalfuinen \& Freitas, 2011). Serious games are the games that support the development in the affective, cognitive or motor skill areas, the person can play with pleasure for a long time without getting bored, and the person experiences the reality presented in the game (Annetta, 2010; Rüppel \& Schatz, 2011; Stalfuinen \& Freitas, 2011). Therefore, knowing which games the students sitting in the school desks are playing today is an important parameter for a successful educational game design.

On the other hand, games are fun activities, however they are also viewed by many individuals as an escape from the stress posed by real life, a pastime activity, or a means to socialization (Cheng, 2007; Yee, 2006). The effects of these approaches can be seen in the individual preferences for different games or for certain behavior specific to different profiles (Giammarco, Schneider, Carswell \& Knipe, 2015; Lazzaro, 2004; Herodotou, Kambouri \& Winters, 2011; Kort-Butler, 2020). An examination of studies dealing with factors affecting individuals' game preferences reveals three main categories: demographic factors (Crawford \& Gosling, 2005; Durdu, Hotomaroğlu \& Çağıltay, 2004; Horzum, 2011; Lucas \& Scherry, 2004; Marshall \& Foran, 2008; Prensky, 2001; Pala \& Erdem, 2011; Quaiser-Pohl, Geiser \& Lehman, 2006; Sherry, De Souza, Greenberg \& Lochan, 2003; Stavropolos, Rennie, Morcos, Gomez \& Griffiths, 2020; Wasserman \& Rittenour, 2019), in-game behavior and motives for playing (Giammarco, Schneider, Carswell \& Knipe, 2015; Lazzaro, 2004; Herodotou, Kambouri \& Winters, 2011; Wang, Sapienza, Culotta \& Ferrara, 2019), and playing habits (Ayan, 2013; Juul, 2002; Kirman \& Lawson, 2009; Lee \& LaRose, 2007; Liao, Tseng, Cheng \& Teng, 2020; Manero, Torrente, Freire \& Fernández-Manjón, 2016; Mulligan \& Patrovsky, 2003; Palomba, 2019; Scharkow, Festl, Vogelgesang \& Quandt, 2015; Tatll, 2018). Thus, despite having different motives for playing, individuals may still choose to play the same game. For example, demographic factors such as gender and age were found to be the most influential variables in determining game preference (Durdu et al., 2005; Lucas \& Scheery, 2004; Pala \& Erdem, 2011; Wasserman \& Rittenour, 2019). A better analysis of game preferences requires a deeper look into the variables of individual's game playing habits (Lee \& LaRose, 2007; Scharkow, Festl, Vogelgesang \& Quandt, 2015), how long (Manero, Torrente, Freire \& Fernández-Manjón, 2016), when (Palomba, 2019), and where (Ayan, 2013; Tatll, 2018) individuals prefer to play the game. The studies examined in this research have all used game types to describe individuals' game preferences. Because of their 
common traits, games are represented under headings which are called game types or game genres, but game types have not been determined according to any scientific standard (Faisal \& Peltoniemi, 2018). As a result, games are often classified differently depending on the researcher. Taking all these into consideration, in order to provide suggestions for an effective educational game design, the participants asked, "Which games would you prefer to play at school?" The question has been posed. Thus, students were enabled to express many game preferences without being limited to educational games. Scientific Research scope has reached 608 students in K-12 level studying Turkey. With this research, the association rule, a type of educational data mining, was applied to predict which games individuals might prefer to play.

The association rule is one of the descriptive models of data mining (Akpinar, 2000). In the literature, clustering and association rule stand out among descriptive models (Ergün, 2008). Clustering reveals the picture of the whole by proceeding through the sub-problems of a problem, and the association rule reveals the possibility of occurring or seeing events together (Agrawal, Imielinski \& Swami, 1993). In this way, it can be determined how events, objects or phenomena are related to each other (Doğan, 2008). For this reason, it was decided to use the association rule in data analysis. In the light of the obtained results, it is aimed to present a road map to game designers and teachers who will design educational games.

\section{Demographic Factors}

Demographic factors are important variables in that they have direct or indirect influence on individual preferences. In fact, many studies have been conducted using demographic factors to identify individuals' game preferences and the games which are appealing to them (Crawford \& Gosling, 2005; Durdu et al., 2005; Horzum, 2011; Lucas \& Scherry, 2004; Marshall \& Foran, 2008; Prensky, 2001; Pala \& Erdem, 2011; Quaiser-Pohl, Geiser \& Lehman, 2006; Sherry, De Souza, Greenberg \& Lochan, 2003; Wasserman \& Rittenour, 2019). Gender has especially been a popular subject of inquiry, frequently being studied for its influence on game preferences. (Crawford \& Gosling, 2005; Horzum, 2011; Prensky, 2001; Quaiser-Pohl et al., 2006; Scharkow et al., 2015). The results of these studies indicate that when compared to women, men not only spend more time playing games (Lucas \& Scherry, 2004; Wasserman \& Rittenour, 2019), but also have a stronger preference for digital games (Durdu et al., 2005). Additionally, male was found to prefer action and simulation games while female's game preferences were predominantly for games which require intelligence (Pala \& Erdem, 2011; Quaiser-Pohl et al., 2006; Scharkow et al., 2015). In light of these findings, it can be assumed that gender is a crucial variable in determining game preferences (Carr, 2005; Crawford \& Gosling, 2005; Durdu et al., 2004; Pala \& Erdem, 2011; Prensky, 2001; Quaiser-Pohl, Geiser \& Lehman, 2006; Tatlı, 2018; Wasserman \& Rittenour, 2019).

Another demographic factor that has been frequently investigated for its influence on game preferences is an individual's age (Durdu et al., 2004; Marshall \& Foran, 2008; Scharkow et al., 2015; Sherry et al., 2003). Several studies reviewed for the purpose of establishing the conceptual framework for the present research indicate that game preferences vary across age groups (Durdu et al, 2004; Scharkow et al., 2015; Sherry et al, 2003). The work of Sherry et al. (2003) presents an example of this effect, where the findings revealed that individuals in the 816 age group preferred competitive and challenging games while those in the 18-23 age group preferred to play traditional games which can be played quickly. Similarly, Scharkow et al. (2015) found that puzzle card games were preferred mostly by older players. Given the fact that games are given age-based ratings by authorized institutions (PEGI, ESRB, etc.), the variation of game preferences across age groups may be interpreted as only natural. However, some recently conducted studies have produced contrary results, indicating that age does not have a significant influence on game preferences (Marshall \& Gorsan, 2008; Pala \& Erdem, 2011). Given the findings of the available literature, therefore, it may not be accurate to suggest that game preferences are directly proportional with age (Pala \& Erdem, 2011).

\section{Player Characteristics}

Games may be described as the oldest form of entertainment ever known, but when it comes to why individuals engage in playing them, the reasons can be wildly divergent. For example, 
Lazzaro (2004) classifies people in terms of their motives for playing (i.e., for their desire to have fun) in four groups: People Fun, Hard Fun, Serious Fun, and Easy Fun. For these four groups, the reasons to play games are, respectively: to feel better, to get a sense of achievement, to overcome an obstacle, to share the enjoyment of the game, or to socialize (Lazzaro, 2004). Along the same line, Giammarco et al. (2015), Herodotu et al. (2011), and Scharkow et al. (2015) suggest that people are compelled to play games owing to their desire for making friends, social satisfaction, achievement and immersion, and their preferences may shift from one game to another based on these motives. For example, people who engage in games for social interaction purposes prefer games that focus on teamwork (Herodotou et al., 2011). On the same issue, Scharkow et al. (2015) assert that it is the strong competitive element of team games, rather than social satisfaction, behind people's preference for team games. On the other hand, Wu et al. (2010) state that social interaction is the most important factor leading the individual to play a particular game. The findings of Heredotou et al. (2011) indicate that competitive games are preferred predominantly by achievement-oriented people. In addition to these results, Giammarco et al. (2015) suggest that people who work in highly competitive fields such as engineering, physics, mathematics, and technology are more interested in playing competitive games.

The main purpose in playing games is to have fun. For this purpose, individuals tend to play different games due to such reasons as personal characteristics, motivations and interests. Conversely, players may engage in the same game due to different factors (Bartle, 1996; Bateman \& Boon, 2005; Nackle, Bateman \& Mandryk, 2011). Among people who prefer to play massively multiplayer online role playing games (MMORPG), Bartle (1996) identifies different types of players, namely: achievers, players with the desire to succeed or to win the game; explorers, those who aim to find bugs and discover unexplored areas; killers, whose main goal is to eliminate opponents; and socializers, who essentially seek social interaction with other players in the game. In a similar study, Bateman and Boon (2005) suggest that it is possible to observe four player profiles: conqueror, manager, wanderer, and participant. A more detailed model is provided by Nackle et al. (2011), where players are classified according to their in-game behavior and their motivation to play into seven types, namely: seeker, daredevil, mastermind, conqueror, socializer, and achiever.

To sum up, the results of the studies examined here indicate that the players' personal characteristics, careers, or areas of interest can lead to a differentiation in their in-game behavior and their motivation to play. It would thus be inappropriate to conclude that a particular type of game is only played by a particular type of person. Therefore, the studies in the literature imply that game design must embrace all players.

\section{Playing Habits}

Habits form in time through interactions with one's physical and social environment. Although games are activities that provide entertaining experiences, many people engage in game play and interact with games as a means of socialization, escape from the stress of real life, and recreation (Cheng, 2007; Yee, 2006). Lee \& LaRose (2007) focus on the correlation between the preferences and the playing habits of individuals, asserting a strong relation between these two variables. The findings of Scharkow et al. (2015), a study conducted with 4500 participants from ages 14-90 playing for an average period of 50 minutes per day, also confirm this correlation.

According to the findings of the available literature, which are examined here, participants predominantly play role playing, strategy, sports, and adventure games, and the reason these games are popular is associated with players' being able to get together with friends (Scharkow et al., 2015). This finding can also be interpreted as evidence for the determinative effect that the environment in which the game is played has on game preference. When game preferences between indoor and outdoor games are compared, the influence of this factor becomes clearer. Ayan (2013) and Tatlı (2018)'s findings suggest that students have a stronger preference for physical games when they are outdoors, and for digital games when they are indoors. Furthermore, game preferences may vary across seasons or even months of the year (Ayan, 2013; Palomba, 2019). For instance, according to a study led by Ayan (2013) which attempted to determine students' game preferences in outdoor environments, it was revealed that students 
prefer snowball in the winter and hide and seek in the summer. Palomba (2019) states that individuals prefer war games in the April-July period, whereas in the July-September period they prefer fighting games.

In recent decades, individuals have started to play games for longer and longer periods of time. Studies show that amongst their daily routines, adults (age 25-35) spend a significant amount of their time (7.5 hours on average per week) playing games (Lee \& LaRose, 2007; Lucas \& Scherrt, 2004). Children and adolescents have a tendency to devote even more time to game play (Eglesz, Fekete, Kiss \& Izó, 2006; Griffiths, Davies \& Chappell, 2004). Monera et al. (2016) investigated the relationship between game preference and amount of time spent playing, and the findings provide evidence for a correlation between the two variables. The results of the same study suggest that players who play for the longest hours, called full gamers, prefer all game types, whereas a second category called hardcore gamers, players who play for relatively fewer hours, prefer first-person or sports games. A third category of players who play regularly is casual gamers. These are people who prefer games with a prominent audio-visual design, and which require mental focus and social interaction. Considering these research results, hours of play can also be accepted as one of the variables affecting individuals' game preferences.

In summary, on the question of what determines individuals' game preferences, the literature focuses on variables such as demographic factors, player characteristics, and game preferences. Although gender and age were found to be important demographic factors in determining game preferences, it is difficult to define these factors as variables on which game preferences depend. Likewise, individuals play games for different reasons and motives (Cheng, 2003; Yee, 2006). Game preferences may diversify or crystallize in relation to these factors, and there is evidence for both in the literature. Therefore, the reasons or motives to play games do not qualify as clear reference points for defining game preferences. However, as for all new product and service design, individuals' past experiences (in other words, habits) can serve as a guide for game design. The studies reviewed here place great emphasis on investigating the playing habits of individuals as determinants of their game preferences. In these studies, individuals' playing habits were examined by focusing on types of games, hours of play, the place and time of play, and game preferences in different spaces.

\section{METHODS}

In the scope of this study, the probable game preferences of individuals were predicted, and the strongly preferred games were reviewed in terms of their design. A description of design principles was sought for the design of popular games or games played by large numbers of people.

As such, this study aimed to define principles for successful design in order to present a tool that will serve as a guide for game designers and educational specialists who wish to provide entertaining experiences. In line with this aim, the relational screening model was used in this study. The relational screening model seeks to determine whether an existing relation between two or more variables actually exists and if so, to identify the direction and intensity of the relation (Karasar, 1986). In this type of study where incident, individuals, and objects are scrutinized within a contextual frame, researchers usually obtain generalizable results (Kerlinger, 1973). The relational screening model does not identify cause and effect relations between variables; it only uses existing relations to help researchers. This it does, as once they know one variable, they can predict the other one (Karasar, 1986).

\section{Research Group}

The research was conducted on 608 elementary school students. The participants were selected using the convenience sampling method. The convenience sampling method is a strategy in which the researcher forms the sample by including objects or people that are easily available to them (Yıldırım \& Şimşek, 2016). This strategy speeds up the research process by saving the researcher much of the time and money spent on sampling. 
This research conducted with a total of 608 students, 371 male and 237 female. Of the students participating in the study, 227 are in primary school and 381 are at the middle school level. It was determined that male middle school students were in the majority among the participants. All demographic information of the participants is summarized in Table 1.

Table 1. Demographic Characteristics of Participants

\begin{tabular}{|c|c|c|c|}
\hline \multirow{2}{*}{ Grade Level } & \multicolumn{2}{|c|}{ Gender } & \multirow{2}{*}{ Tota } \\
\hline & Male & Female & \\
\hline Grade 1 & 21 & 18 & 39 \\
\hline Grade 2 & 37 & 22 & 59 \\
\hline Grade 3 & 34 & 39 & 73 \\
\hline Grade 4 & 38 & 18 & 56 \\
\hline Grade 5 & 69 & 33 & 102 \\
\hline Grade 6 & 63 & 35 & 98 \\
\hline Grade 7 & 56 & 45 & 101 \\
\hline Grade 8 & 53 & 27 & 80 \\
\hline Total & 371 & 237 & 608 \\
\hline
\end{tabular}

Data Collection

An assessment tool with open-ended questions was used, consisting of questions about demographic factors (grade level and gender) and about which games the students would like to play at school. Neither game name or game genre weren't specified in the data collection tool in order not to restrict the participants to any type of game and to examine their game habits in depth. Within the scope of the research, it is aimed to reach a large research group. Thus, it was carried out with a private school students with research campus in many provinces of Turkey. Therefore, the participants shared their answers with the researchers on an online platform via the link sent to them. During the data collection process, all the responses of the participants were recorded in the system anonymously and the protection of their personal data was tried to be maintained. In addition, researchers have considered the ethical rules during all steps of research.

\section{Data Analysis}

The student responses were extracted into a list through the system. First, the data were organized and structured for analysis. Then, the structured data were analyzed using the association rule. The association rule is an analysis method commonly used in problem situations like catalog design, product placement planning in stores, developing sales strategies, boosting sales, and understanding shopping trends (Agrawal et. al., 1993, 1993). The association rule is one of the descriptive models of data mining (Akpinar, 2000). In the literature, clustering and association rule stand out among descriptive models (Ergün, 2008). Clustering reveals the picture of the whole by proceeding through the sub-problems of a problem, and the association rule reveals the possibility of occurring or seeing events together (Agrawal, Imielinski \& Swami, 1993). In this way, it can be determined how events, objects or phenomena are related to each other (Doğan, 2008). For this reason, it was decided to use the association rule in data analysis. In the light of the obtained results, it is aimed to present a road map to game designers and teachers who will design educational games.

In other words, an analysis using the association rule makes it possible to define relations between otherwise isolated events, allowing the representation of relations in the form of $\mathrm{X} \rightarrow \mathrm{Y}$. So it can be said that the association rule helps to reveal how facts and concepts are related. The data obtained are presented together with support and confidence values. The support value is a percentage value which shows how frequently the rule appears in the data set (Agrawal et. al., 1993; Merceron et al., 2010). This value is calculated using the following formula;

$$
\text { Support }=\frac{n(X \cup Y)}{N}
$$


$n(X \cup Y)$ represents events in which $\mathrm{X}$ and $\mathrm{Y}$ are found together, while $\mathrm{N}$ represents the number of events. Confidence is a percentage value indicating how frequently $Y$ appears in events where $\mathrm{X}$ is present (Agrawal et. al.., 1993; Merceron et al., 2010). This value is calculated using the following formula;

$$
\text { Confidence }=\frac{n(X \cup Y)}{n(X)}
$$

In the formula used for calculating the confidence value; $n(X \cup Y)$ represents the number of events in which both $\mathrm{X}$ and $\mathrm{Y}$ are found together, and $\mathrm{n}(\mathrm{X})$ represents the number of all events in which $\mathrm{X}$ is found. A case where the confidence value is zero is only possible when the $\mathrm{n}(\mathrm{X} \cup \mathrm{Y})$ value is zero, which indicates a situation in which no events are observed where both $\mathrm{X}$ and $\mathrm{Y}$ are found together (Özçalıcl, 2017). The association rule is generally preferred when estimation is required in studies involving qualitative data (Akpınar, 2000). Therefore, the relationship of objects and phenomena with each other can be revealed by association rule (Doğan, 2008). Since it was aimed to present a road map to game designers and teachers who will design educational games in the light of the results obtained, the prominent game preferences of the participants were analyzed on the basis of the GameFlow (Sweetzer \& Wheyh, 2005) scale. GameFlow is a scale aimed at evaluating a gaming experience (Sweetzer \& Wheyh, 2005). The scale criteria were determined based on 8 factors (consent, challenge, player skills, control, clear goals, feedback, immersion and social interaction) for game design and an individual's flow experience (Csikszetmihalyi, 1999). These criteria are summarized in Table 2.

Table 2. Factor of scale, their descriptions and examples (Sweetzer \& Wheyh, 2005)

\begin{tabular}{|c|c|c|c|}
\hline Factors & Description & Example & Point \\
\hline Consentrarion & $\begin{array}{l}\text { Game should require } \\
\text { concentration and the player } \\
\text { should be able to concentrate on } \\
\text { game. }\end{array}$ & $\begin{array}{l}\text { Animation } \\
\text { Sound } \\
\text { Graphics } \\
\text { Game interface }\end{array}$ & 30 \\
\hline Challenge & $\begin{array}{l}\text { Games should be sufficiently } \\
\text { challenging and match the } \\
\text { player's skill level. }\end{array}$ & $\begin{array}{l}\text { Diffuculty of game } \\
\text { task/mission }\end{array}$ & 20 \\
\hline Player Skills & $\begin{array}{l}\text { Game must support player skill } \\
\text { development and mastery. }\end{array}$ & $\begin{array}{l}\text { Online help } \\
\text { Tutorial }\end{array}$ & 35 \\
\hline Control & $\begin{array}{l}\text { Players should feel a sense of } \\
\text { control over their action in the } \\
\text { game. }\end{array}$ & $\begin{array}{l}\text { User-friendly } \\
\text { interface/device } \\
\text { Clear icon }\end{array}$ & 30 \\
\hline Clear Goal & $\begin{array}{l}\text { Games should provide the player } \\
\text { with clear goals at appropriate } \\
\text { times. }\end{array}$ & Specific Mission & 10 \\
\hline Feedback & $\begin{array}{l}\text { Players must receive appropriate } \\
\text { feedback at appropriate times. }\end{array}$ & $\begin{array}{l}\text { Visual and auditory } \\
\text { feedback }\end{array}$ & 15 \\
\hline Immersion & $\begin{array}{l}\text { Players should experience deep } \\
\text { but efortless involvement in the } \\
\text { games. }\end{array}$ & $\begin{array}{l}\text { Monitoring } \\
\text { Story }\end{array}$ & 25 \\
\hline $\begin{array}{l}\text { Social } \\
\text { Interaction }\end{array}$ & $\begin{array}{l}\text { Games should support and create } \\
\text { opportunities for social } \\
\text { interaction. }\end{array}$ & $\begin{array}{l}\text { Chat } \\
\text { Communication option }\end{array}$ & 15 \\
\hline Total & & & 180 \\
\hline
\end{tabular}

Considering the GameFlow scale, the fact that a game experience can be fun is associated with many different factors. At this point, the game is expected to be neither too easy nor to contain obstacles and targets with appropriate difficulty for the player. On the other hand, for a fun game experience, the player must be able to concentrate and feel the control within the game. In addition, the player's ability to receive feedback at the right time and be able to interact socially 
supports the player's game experience positively. The outstanding games within the scope of the research were evaluated according to this scale. In order to ensure the reliability of the data analysis process, the games were examined by two raters (Joffe, 2011). Then, it was determined that the raters gave 95\% similar scores with the formula of Miles and Huberman (1994).

\section{Limitations}

The study group of the research is limited to students who are volunteering to participate in the study at primary and secondary school levels. In addition, the research group consists of only students studying at a private institution. In order to increase the participation of these students in the research and not to direct the participants, a data collection tool limited to a few questions was used.

\section{RESULTS}

In this section, research findings regarding the participating students' the games they may prefer to play at school, and predictions regarding their probable game preferences are presented.

\section{The Games Participants Prefer to Play at School}

Participants responded to the question, "Which games do you prefer to play at school?". According to all participant answers, football, hide and seek, basketball, up and down tag, volleyball, Minecraft, Taboo, blind man's buff, Monopoly, tag, Counter Strike Global Offensive (CS:GO), GTA, table tennis, and PUBG are determined as the games that the participants want to play at school. All male students frequently responded that they like to play football, basketball, Minecraft, CSGO, hide and seek, Monopoly, dodge ball, GTA, LOL, and PUBG at school. On the other hand, all female students frequently responded that they like to play hide and seek, volleyball, Monopoly, up and down tag, Minecraft, Taboo, blind man's buff, dodge ball, tag, and basketball. These answers belong to all participant.

Similarly, student responses were sorted by grade level. It was found that primary school (Grades 1, 2, 3, and 4) students preferred football, hide and seek, Minecraft, up and down tag, basketball, tag, volleyball, blind man's bluff, and Monopoly. This finding can be interpreted as a preference for physical games at the primary level of education. The responses of secondary school students (Grades 5, 6, 7, and 8) included digital games like Minecraft, CSGO, LOL, PUBG, FIFA, and PES as well as football, hide and seek, basketball, and Monopoly.

\section{The Probable Game Preferences of Participants}

An analysis of game preferences was made on student responses, and 31 rules were identified with a 0.70 minimum confidence threshold and 0.10 minimum support threshold. The rules calculated at the minimum confidence and support levels obtained from analysis results are demonstrated in Table 3.

When Table 4 is analyzed, it is seen that there are 31 rules for playing Minecraft, Football, Basketball, Monopoly and Hide and Seek in a total of 96 games that the participants stated to be playing. According to this point of view, when the current game preferences that are not preferred to play these 5 games but according to the association rule analysis analysis (min. Supp $=0.11$ and max. Supp = 0.21), the game preferences of the participants and the GameFlow scale sub-category scores of these games should be examined. For this, 5 games preferences as a result of 31 rules are given in subcategories.

Table 3. Rules calculated at minimum confidence and support levels obtained by an analysis of participants'game preferences.

\begin{tabular}{ccccc}
\hline Rule (R) & $\mathbf{X}$ & $\mathbf{Y}$ & Support (supp) & $\begin{array}{c}\text { Confidence } \\
\text { (conf) }\end{array}$ \\
\hline 1 & Monopoly & Minecraft & 0.21 & 0.74 \\
2 & Basketball, Football & Minecraft & 0.15 & 0.74
\end{tabular}




\begin{tabular}{|c|c|c|c|c|}
\hline 3 & Basketball, Minecraft & Football & 0.15 & 0.74 \\
\hline 4 & Football, Minecraft & Basketball & 0.15 & 0.74 \\
\hline 5 & Basketball, Minecraft & Monopoly & 0.15 & 0.74 \\
\hline 6 & Basketball, Monopoly & Minecraft & 0.15 & 0.88 \\
\hline 7 & Volleyball & Minecraft & 0.14 & 0.72 \\
\hline 8 & Volleyball & Monopoly & 0.14 & 0.72 \\
\hline 9 & Blindman's Buff & $\begin{array}{l}\text { Hide and } \\
\text { Seek }\end{array}$ & 0.13 & 0.80 \\
\hline 10 & Taboo & Monopoly & 0.13 & 0.71 \\
\hline 11 & Up and Down Tag & $\begin{array}{l}\text { Hide and } \\
\text { Seek }\end{array}$ & 0.13 & 0.75 \\
\hline 12 & Basketball, Monopoly & Football & 0.13 & 0.75 \\
\hline 13 & Football, Monopoly & Basketball & 0.13 & 0.86 \\
\hline 14 & Football, Monopoly & Minecraft & 0.13 & 0.86 \\
\hline 15 & Basketball, Hide and Seek & Minecraft & 0.12 & 0.79 \\
\hline 16 & Football, Hide and Seek & Minecraft & 0.12 & 0.79 \\
\hline 17 & Monopoly, Hide and Seek & Minecraft & 0.12 & 0.79 \\
\hline 18 & Minecraft, Volleyball & Monopoly & 0.12 & 0.85 \\
\hline 19 & Monopoly, Volleyball & Minecraft & 0.12 & 0.85 \\
\hline 20 & $\begin{array}{l}\text { Basketball, Football, } \\
\text { Minecraft }\end{array}$ & Monopoly & 0.12 & 0.79 \\
\hline 21 & $\begin{array}{l}\text { Basketball, Football, } \\
\text { Monopoly }\end{array}$ & Minecraft & 0.12 & 0.92 \\
\hline 22 & $\begin{array}{l}\text { Basketball, Minecraft, } \\
\text { Monopoly }\end{array}$ & Football & 0.12 & 0.79 \\
\hline 23 & $\begin{array}{l}\text { Football, Minecraft, } \\
\text { Monopoly }\end{array}$ & Basketball & 0.12 & 0.92 \\
\hline 24 & Basketball, Hide and Seek & Football & 0.11 & 0.71 \\
\hline 25 & Football, Hide and Seek & Basketball & 0.11 & 0.71 \\
\hline 26 & Basketball, Hide and Seek & Monopoly & 0.11 & 0.71 \\
\hline 27 & Monopoly, Hide and Seek & Basketball & 0.11 & 0.71 \\
\hline 28 & CSGO, Minecraft & Monopoly & 0.11 & 0.71 \\
\hline 29 & CSGO, Monopoly & Minecraft & 0.11 & 0.83 \\
\hline 30 & Football, Volleyball & Minecraft & 0.11 & 0.91 \\
\hline 31 & Minecraft, Volleyball & Football & 0.11 & 0.77 \\
\hline
\end{tabular}




\section{Possible Minecraft players}

The rules presented in Table 4 imply that students who play the following games; R1 "Monopoly" (supp: 0.21; conf: 0.74), R2 "Basketball and Football” (supp: 0.15; conf: 0.74), R6 "Basketball and Monopoly" (supp: 0.15; conf: 0.88), R7 "Volleyball" (supp: 0.14; conf: 0.72), R14 "Football and Monopoly" (supp: 0.13; conf: 0.86), R15 “Basketball and Hide \& Seek" (supp: 0.12; conf: 0.79), R16 "Football and Hide \& Seek" (supp: 0.12; conf: 0.79), R17 "Monopoly and Hide \& Seek" (supp: 0.12; conf: 0.79), R19 "Monopoly and Volleyball" (supp: 0.12; conf: 0.85), R22 "Basketball and Football and Monopoly" (supp: 0.12; conf: 0.92), R31 "CSGO and Monopoly" (supp: 0.11; conf: 0.83), R32 "Football and Volleyball" (supp: 0.11; conf: 0.91) also prefer to play Minecraft (Figure 1.).

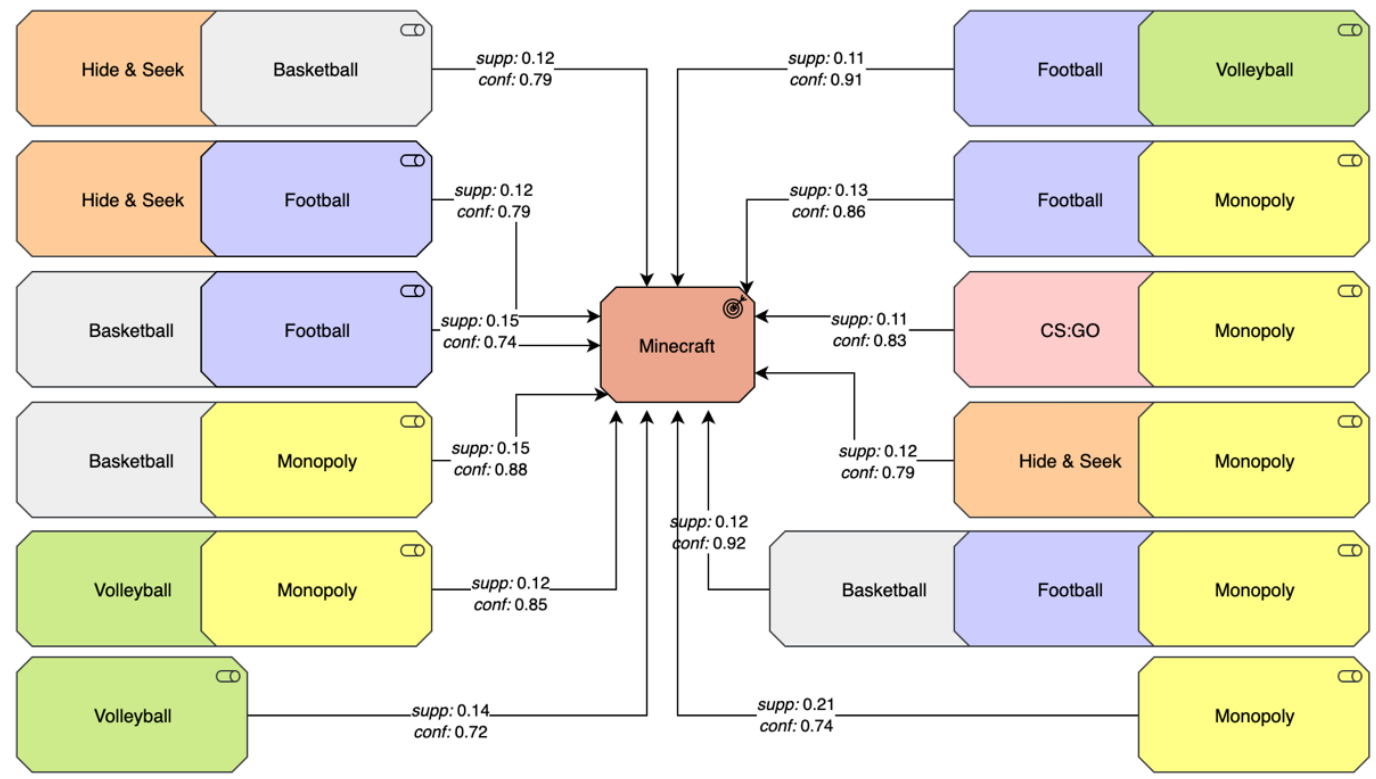

FIGURE 1. Playing Minecraft probability rules

When Figure 1 is examined, it is seen that the game with the highest support value is Monopoly. This rule also has the highest support value of all rules. This finding can be stated that students who prefer to play Monopoly but do not play Minecraft yet, are more likely to continue playing this game when they play Minecraft (conf: 0.74). However, with physical games like basketball, volleyball or football, those who play Monopoly or hide \& seek are likely to prefer Minecraft again. It would be useful to support this finding and look at GameFlow scale points on what elements of students who are likely to choose Minecraft can play this game (Table 4).

When Table 5 is examined, one of the most important findings that draw attention is that the challenge element scores of the games are the same $(p=8)$ except CS: GO $(p=19)$. However, while the clear goals element scores of all games are the same $(p=10)$, the low score of Minecraft game $(p=2)$ is another remarkable finding. Social interaction scores of all games are equally distributed $(\mathrm{p}=15)$. The total scores of other elements differ equally in some games and slightly in some games.

Table 4. Basketball, football, volleyball, CS:GO, hide \&seek, Monopoly, Minecraft GameFlow point (Sweetzer \& Wheyh, 2005)

\begin{tabular}{|c|c|c|c|c|c|}
\hline \multirow{3}{*}{ Elements } & \multicolumn{5}{|c|}{ Total Points devided by Category (p) } \\
\hline & \multicolumn{4}{|c|}{ Actually Play } & $\begin{array}{c}\text { Possibility to } \\
\text { Play }\end{array}$ \\
\hline & $\begin{array}{l}\text { Basketball, Football } \\
\text { \& Volleyball }\end{array}$ & CS:GO & $\begin{array}{l}\text { Hide \& } \\
\text { Seek }\end{array}$ & Monopoly & Minecraft \\
\hline
\end{tabular}




\begin{tabular}{cccccc}
\hline Concentration & 16 & 20 & 17 & 14 & 18 \\
Challenge & 8 & 19 & 8 & 8 & 8 \\
Player Skills & 23 & 27 & 23 & 20 & 22 \\
Control & 18 & 25 & 19 & 20 & 25 \\
Clear Goals & 10 & 10 & 10 & 10 & 2 \\
Feedback & 11 & 15 & 11 & 11 & 11 \\
Immersion & 20 & 20 & 20 & 15 & 15 \\
Social & 15 & 15 & 15 & 15 & 15 \\
Interaction & 119 & 160 & 133 & 121 & 123 \\
Total & & & & \\
\hline
\end{tabular}

\section{Possible football players}

And secondly, the rules presented in Table 3 shows that; R3 "Basketball and Minecraft" (supp: 0.15; conf: 0.74), R12 "Basketball and Monopoly" (supp: 0.13; conf: 0.75), R22 "Basketball and Minecraft and Monopoly" (supp: 0.12; conf: 0.79), R24 "Basketball and Hide \& Seek" (supp: 0.11; conf: 0.71), R31 "Minecraft and Volleyball" (supp: 0.11; conf: 0.77) players also prefer to play Football (Figure 2).

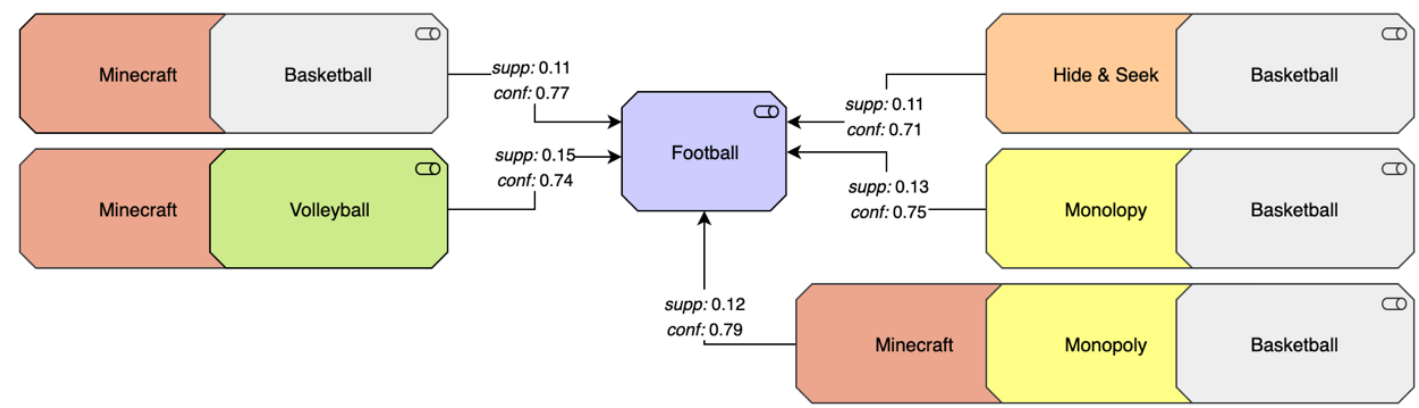

FIGURE 2. Playing football probability rules

When Fig. 2 is examined, it is determined that the games of the highest support value are Minecraft, Monopoly and basketball. This finding shows that students who prefer to play football but have not yet experienced these games can continue to play these three games after meeting these games. Volleyball (conf. 0.74) and hide and seek of similar situation conf. It is possible to say that it is valid for 0.71). It would be useful to support these findings and look at GameFlow scale scores on the elements of why students who are likely to play the football game can choose this game (Table 5).

If Table 5 is examined, it is seen that the clear goal element scores $(p=10)$ of the games are similar except for Minecraft $(\mathrm{p}=2)$. There is very small score differences between games in other elements. However, the fact that the social interaction score of the games $(p=15)$ is the same is another important finding of this table.

Table 5. Basketball, volleyball, hide \&seek, Monopoly, Minecraft GameFlow point (Sweetzer \& Wheyh, 2005)

\begin{tabular}{ccccc}
\hline & \multicolumn{3}{c}{ Total Points devided by Category (p) } \\
\cline { 2 - 5 } Elements & \multicolumn{3}{c}{ Actually Play } & $\begin{array}{c}\text { Possibility } \\
\text { to Play }\end{array}$ \\
\cline { 2 - 5 } & $\begin{array}{c}\text { Basketbal, \& } \\
\text { Voleyball }\end{array}$ & Hide \& Seek & Monopoly & Minecraft \\
\hline Concentration & 16 & 17 & 14 & 18 \\
Challenge & 8 & 8 & 8 & 8 \\
Player Skills & 23 & 23 & 20 & 22 \\
Control & 18 & 19 & 20 & 25 \\
\hline
\end{tabular}




\begin{tabular}{ccccc}
\hline Clear Goals & 10 & 10 & 10 & 2 \\
Feedback & 11 & 11 & 11 & 11 \\
Immersion & 20 & 20 & 15 & 15 \\
Social & 15 & 15 & 15 & 15 \\
Interaction & 119 & 133 & 121 & 123 \\
Total & & & & \\
\hline
\end{tabular}

\section{Possible basketball players}

And thirdly, the rules presented in Table 4 shows that; R4 "Football and Minecraft" (supp: 0.15; conf: 0.74), R13 "Footbal and Monopoly" (supp: 0.13; conf: 0.86), R23 "Footbal and Minecraft and Monopoly" (supp: 0.12; conf: 0.92), R25 "Footbal and Hide \& Seek" (supp: 0.11; conf: 0.71), R27 "Monopoly and Hide and Seek" (supp: 0.11; conf: 0.71) players also prefer to play Football (Figure 3).

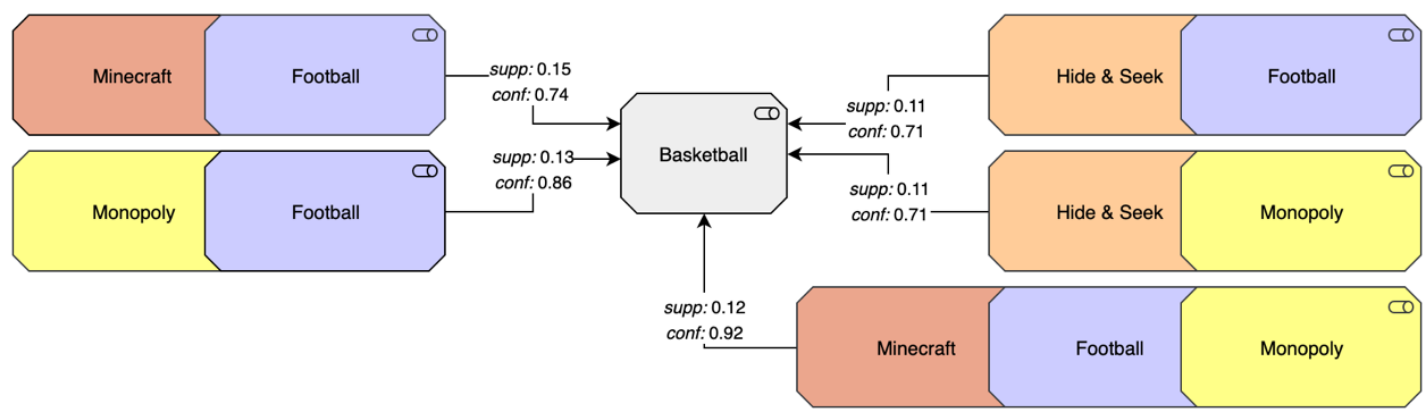

FIGURE 3. Playing basketball probability rules

When the Figure 3 is examined, it is determined that the games with the highest support value are Minecraft, and Football, which shows that a student who plays basketball but has never played Minecraft and Football will continue to play this game after meeting these games. Similarly, it can be said that those who have never experienced games like Hide \& seek (conf. 0.71) and Monopoly will continue to play. In addition to these findings, it will be useful to examine the GameFlow scale scores of the students who are likely to play basketball games for other possible game preferences (Table 6).

When Table 6 is examined, it is seen that the findings determined are very similar to Table 5. Therefore, it can be said that the reasons that lead individuals to play basketball and football to play these games are similar.

Table 6. Football, hide \&seek, Monopoly, Minecraft GameFlow point (Sweetzer \& Wheyh, 2005)

\begin{tabular}{ccccc}
\hline & \multicolumn{4}{c}{ Total Points devided by Category (p) } \\
\cline { 2 - 5 } Elements & \multicolumn{3}{c}{ Actually Play } & $\begin{array}{c}\text { Possibility to } \\
\text { Play }\end{array}$ \\
\cline { 2 - 5 } & Football & Hide \& Seek & Monopoly & Minecraft \\
\hline Concentration & 16 & 17 & 14 & 18 \\
Challenge & 8 & 8 & 8 & 8 \\
Player Skills & 23 & 23 & 20 & 22 \\
Control & 18 & 19 & 20 & 25 \\
Clear Goals & 10 & 10 & 10 & 2 \\
Feedback & 11 & 11 & 11 & 11 \\
Immersion & 20 & 20 & 15 & 15 \\
Social & 15 & 15 & 15 & 15 \\
Interaction & 119 & 133 & 121 & 123 \\
Total & & &
\end{tabular}




\section{Possible Monopoly players}

And fourthly, the rules presented in Table 4 shows that; R5 "Basketball and Minecraft" (supp: 0.15; conf: 0.74), R8 "Volleyball” (supp: 0.14; conf: 0.72), R10 “Taboo" (supp: 0.13; conf: 0.71), R18 "Minecraft and Volleyball" (supp: 0.12; conf: 0.85), R20 "Basketball and Football and Minecraft" (supp: 0.12; conf: 0.79), R26 "Basketball and Hide \& Seek" (supp:0.11; conf:0.71) players also prefer to play Football (Figure 4).

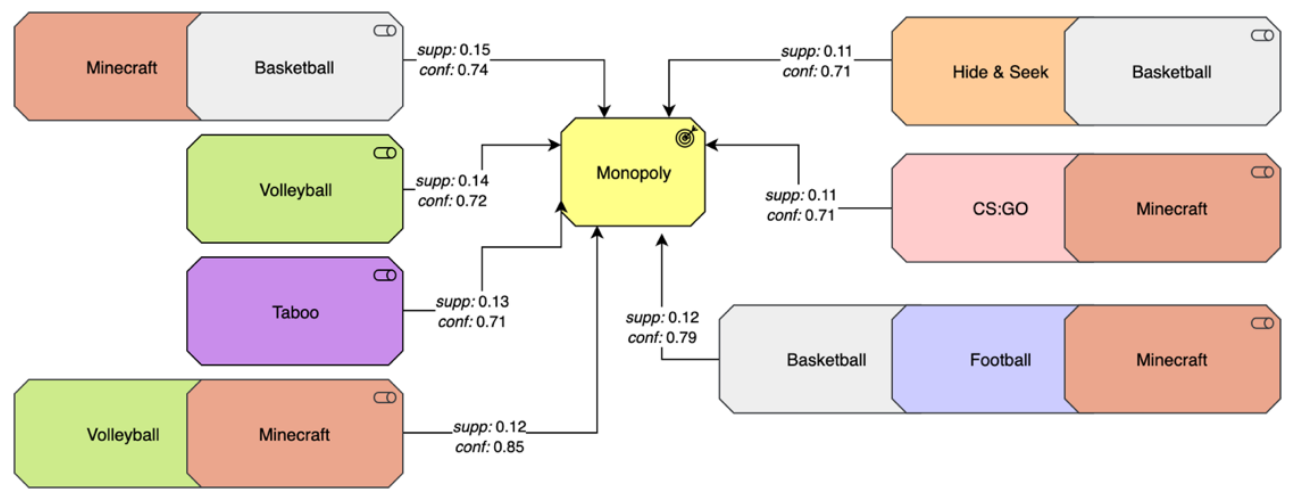

FIGURE 4. Playing Monopoly probability rules

When Fig 4. is examined, it is seen that the games with the highest support value are Minecraft and Basketball. Therefore, it shows that a student who plays basketball but has never played Minecraft and Basketball will continue to play this game after meeting these games. Similar situation volleyball and Minecaft (conf. 0.85), basketball, football and Minecraft (conf. 0.79), volleyball (conf .: 0.72), CS:GO and Minecraft (conf .: 071), Taboo (conf.:0.71), Applies to hide and seek and basketball (conf.: 0ş71) games. In addition to these findings, it will be useful to examine the GameFlow scale scores of the students who are likely to play the Monopoly game for other possible game preferences (Table 7).

Table 7. Basketball, football, volleyball, CS:GO, hide \&seek, Taboo, Minecraft GameFlow point (Sweetzer \& Wheyh, 2005)

\begin{tabular}{|c|c|c|c|c|c|}
\hline \multirow{3}{*}{ Elements } & \multicolumn{5}{|c|}{ Total Points devided by Category (p) } \\
\hline & \multicolumn{4}{|c|}{ Actually Play } & \multirow{2}{*}{$\begin{array}{c}\begin{array}{c}\text { Possibility } \\
\text { to Play }\end{array} \\
\text { Minecraft }\end{array}$} \\
\hline & $\begin{array}{c}\text { Basketbal, Football \& } \\
\text { Voleyball }\end{array}$ & CS:GO & $\begin{array}{c}\text { Hide \& } \\
\text { Seek }\end{array}$ & Taboo & \\
\hline Concentration & 16 & 20 & 17 & 16 & 18 \\
\hline Challenge & 8 & 19 & 8 & 8 & 8 \\
\hline Player Skills & 23 & 27 & 23 & 22 & 22 \\
\hline Control & 18 & 25 & 19 & 19 & 25 \\
\hline Clear Goals & 10 & 10 & 10 & 10 & 2 \\
\hline Feedback & 11 & 15 & 11 & 15 & 11 \\
\hline Immersion & 20 & 20 & 20 & 19 & 15 \\
\hline $\begin{array}{c}\text { Social } \\
\text { Interaction }\end{array}$ & 15 & 15 & 15 & 15 & 15 \\
\hline Total & 119 & 160 & 133 & 133 & 123 \\
\hline
\end{tabular}

When Table 7 is examined, the first finding is that both clear goal element scores $(p=10)$ of Minecraft $(p=2)$ and challenge scores $(p=8)$ are similar except for CS: GO $(p=19)$. In other elements, there are very small score differences between the scores of the games. However, the fact that the social interaction score of the games $(p=15)$ is the same is another important finding of this table. In addition, by examining the game literature, the sine qua non of a game design is 
determined as game rules, challenges, goals, feedback, player action and material. Then, the games preferred by the participants are examined in the game literature based on the essential elements in the design of a game and are presented in Table 8.

When game design elements of the students' preferred games are examined; it is obvious that students tend to prefer to play more physical games that they can play as a team (Table 8). This finding may be the most important proof of the similarity in "Social Interaction" at GameFlow scale. In addition, students tend to prefer to games which have clear and authentic rules. According to Table 8, while running as a player action stands out among the player actions, time is the most frequent challenge factor in game design. Finally, in order to summarize whether the player has done the right or wrong and the situation in the game in the games of their choice, it is most commonly used for score, life (chance to play again) and progress bar as feedback (Table 8). It can be said that similar feedback types were included in the design of the games that the participants preferred, and that these games were effective in getting close scores in the "feedback" field in GameFlow scale.

In summary, obtained from both the association rule and the evaluations on the GameFlow scale show that the participants enjoy playing team games more. In addition, it was found that the participants tend to prefer games that have clear rules and can get regular feedback. According to findings, it can be also said that the participants prefer to play games in which they are both mentally and physically active. Therefore, games that challenge them or require a fight against the opponent stand out among the preferences of the participants. 
Table 8. Game design elements of students' preferred game

\begin{tabular}{|c|c|c|c|c|c|c|c|c|}
\hline \multirow{2}{*}{ Game } & \multirow{2}{*}{$\begin{array}{l}\text { Game } \\
\text { Type }\end{array}$} & \multirow{2}{*}{ How? } & \multicolumn{6}{|c|}{ Game Design Elements } \\
\hline & & & Rule & Challenge & Goal & Player Action & Feedback & Materials \\
\hline Basketballl & $\begin{array}{l}\text { Physical } \\
\text { Game }\end{array}$ & Indiviually & Authentic & $\begin{array}{c}\text { Time } \\
\text { Opponent } \\
\text { Hand bounce }\end{array}$ & To be winner & $\begin{array}{c}\text { To run } \\
\text { To make a } \\
\text { basket }\end{array}$ & Score & $\begin{array}{c}\text { Ball } \\
\text { Court }\end{array}$ \\
\hline $\begin{array}{c}\text { Blindman's } \\
\text { Buff }\end{array}$ & $\begin{array}{c}\text { Physical } \\
\text { Game }\end{array}$ & Indiviually & Authentic & Playing Blindfold & $\begin{array}{c}\text { To be accurately } \\
\text { guess }\end{array}$ & $\begin{array}{l}\text { To guess } \\
\text { To know }\end{array}$ & Player answer & Blindfold \\
\hline CSGO & $\begin{array}{l}\text { Digital } \\
\text { Game }\end{array}$ & Team & Authentic & $\begin{array}{c}\text { Other players } \\
\text { Enemies } \\
\text { Game } \\
\text { environments }\end{array}$ & $\begin{array}{c}\text { To complete mission } \\
\text { To survive }\end{array}$ & $\begin{array}{l}\text { To run } \\
\text { To shoot }\end{array}$ & $\begin{array}{c}\text { Score } \\
\text { Player progress } \\
\text { Leader Board }\end{array}$ & PC \\
\hline Dodgeball & $\begin{array}{l}\text { Physical } \\
\text { Game }\end{array}$ & Team & Authentic & It & $\begin{array}{l}\text { To eliminate all } \\
\text { members of the } \\
\text { opposing team }\end{array}$ & $\begin{array}{l}\text { To Throw } \\
\text { To Run } \\
\text { To Jump }\end{array}$ & Live & Ball \\
\hline Football & $\begin{array}{l}\text { Physical } \\
\text { Game }\end{array}$ & Indiviually & Authentic & $\begin{array}{c}\text { Time } \\
\text { Opponent }\end{array}$ & To be winner & $\begin{array}{c}\text { To run } \\
\text { To score a goal }\end{array}$ & Score & $\begin{array}{c}\text { Ball } \\
\text { Ground }\end{array}$ \\
\hline $\begin{array}{c}\text { Hide and } \\
\text { Seek }\end{array}$ & $\begin{array}{c}\text { Physical } \\
\text { Game }\end{array}$ & $\begin{array}{c}\text { Team / } \\
\text { Indiviually }\end{array}$ & Authentic & $\begin{array}{c}\text { Time } \\
\text { It }\end{array}$ & To don't to be it & $\begin{array}{l}\text { To hide } \\
\text { To seek }\end{array}$ & To find out by it & Ground \\
\hline Minecraft & $\begin{array}{c}\text { Digital } \\
\text { Game }\end{array}$ & Indiviually & Authentic & Open world & 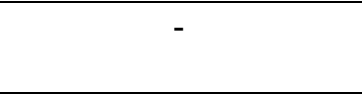 & $\begin{array}{c}\text { To code } \\
\text { To build } \\
\end{array}$ & - & $\mathrm{PC}$ \\
\hline Monopoly & $\begin{array}{l}\text { Board } \\
\text { Game }\end{array}$ & Team & Authentic & $\begin{array}{c}\text { Dice } \\
\text { Budget }\end{array}$ & To gain most money & $\begin{array}{c}\text { To spend } \\
\text { money } \\
\text { To gain money }\end{array}$ & Go bankrupt & $\begin{array}{l}\text { Board } \\
\text { Pawn } \\
\text { Dice }\end{array}$ \\
\hline Taboo & $\begin{array}{l}\text { Board } \\
\text { Game }\end{array}$ & Team & Authentic & $\begin{array}{c}\text { Time } \\
\text { Banned word }\end{array}$ & To be winner & $\begin{array}{c}\text { To guess } \\
\text { To tell }\end{array}$ & $\begin{array}{c}\text { Player progress } \\
\text { on the game } \\
\text { board }\end{array}$ & $\begin{array}{c}\text { Board } \\
\text { Pawn } \\
\text { Puppet }\end{array}$ \\
\hline Voleyball & $\begin{array}{l}\text { Physical } \\
\text { Game }\end{array}$ & Team & Authentic & $\begin{array}{c}\text { Time } \\
\text { Opponent } \\
\text { Hand bounce } \\
\end{array}$ & To be winner & $\begin{array}{c}\text { To run } \\
\text { To make a } \\
\text { basket }\end{array}$ & Score & $\begin{array}{c}\text { Ball } \\
\text { Court }\end{array}$ \\
\hline
\end{tabular}




\section{DISCUSSION and CONCLUSIONS}

Games, despite their deep roots in history, have now become industrial products, which, putting together all the software, hardware, and in-game purchase items, create a massive billiondollar market (Boyle, Connolly, Hainey \& Boyle, 2012; Lee \& LaRose, 2007). It would not be wrong to state that games have become a leading industry. As an expected consequence of the growth in this industry, those who wish to have a slice of the pie are constantly on the lookout and in competition for game design that will keep players playing and be commercially successful.

Games have a positive influence on the development of many skills such as academic achievement (Barzilai \& Blau, 2014; Sung \& Hwang, 2013; Tsai et al., 2016), learning motivation (Burguillo, 2010; Erhel \& Jamet, 2013), and creative thinking (Bulut, 2015). Hence, the need for quality game design is a major concern, not only for the entertainment industry but also for educational specialists. In the literature, various models for game design are proposed to serve as a guide for educational specialists (Amory, 2007; Amory \& Seagram, 2003; Kaplan \& Çağıltay, 2006; Song \& Zhong, 2008; Zin, Jaafar \& Yue, 2009). While these models provide useful general instructions for each phase of the design process, an extensive and clear course of action capturing the essential features of robust, high quality game design is yet to be developed (Boyle et al., 2012). The need for a model becomes even more significant when one considers the difficulty in satisfying both the game designer's concern for commercial success and the educational specialist's concern for creating efficient learning environments $(\mathrm{Wu}$, Wang \& Tsai, 2010). This study provides a review of the field literature, a summary of individuals' playing habits, inferences about which games they may possibly prefer, and these games' features.

One of the striking results of the study is that today's students, who are called digital natives (Presnky, 2001), prefer to play physical games such as football, hide-and-seek, basketball and high above the ground. According to Prensky (2001), digital natives are a generation who prefer to use digital technology for most of their lives, including their basic needs such as acquiring information, communicating and socializing. Therefore, it is thought that digital natives are more interested in digital games (Roodt \& Saunders, 2017). However, the results of the research contrast with this prediction. On the other hand, within the scope of the research, among the game preferences of the students, there are games such as CS: GO and GTA, which are determined to be suitable for adults by organizations such as PEGI and ESRB. This result indicates that students do not play games suitable for their age group. Therefore, students need to be directed to games suitable for their age and development.

Other results of this study can be summarized as follows: Students who play Monopoly are likely to play Minecraft; students most likely play Minecraft if they play basketball and football, basketball and Monopoly, volleyball, football and Monopoly, or Monopoly and volleyball. In addition, the results indicate with $91.6667 \%$ confidence that students who play football, basketball, and Monopoly are likely to prefer Minecraft.

Since the aim of the study was to present a road map for the game design process, the game preferences of the students were taken into consideration and the similarities and differences between the games were determined in terms of design (Cornett, 2004; Lin \&Wang, 2014; Pachet \& Addressi, 2004). Football, basketball, and volleyball were distinguished by being team games with time limits and authentic rules. Furthermore, the player action of games under examination were found to be similar in specific ways. To illuminate, an example from the research results for these two types can be found in the game of dodgeball. In dodgeball, player actions are throwing the ball and jumping out of the ball's way. At the same time, catching the ball in the air earns the player lives. An analysis of player actions on the most preferred games suggests that running, throwing, jumping, moving ahead, buying, selling, coding, and creating are the most striking actions. It can be said that these player actions promote the physical and cognitive development of the individual. In the literature, the most frequently preferred game mechanics are found to be matching, arranging, selecting, grouping, and searching (Trefry, 2010).

In addition to this, the literature recommends using several player actions in order to enrich the game experience and make the game more entertaining (Trefry, 2010). When the 
design of the games preferred by participants was examined, the results were found to support this proposition. The player action of football, basketball, volleyball, Monopoly, and Minecraft can be ranked as running, chasing, coding, creating, and buying or selling. In all these games, more than one player action is used. Thus, the frequently preferred player action can be considered, and more than one game mechanic can be integrated into the design in order to provide a richer game experience.

The similarities between the games preferred by participants are not only about player action but also about game goal. For example, the goal of football, basketball, and volleyball is to win the game by scoring more than the opposing team. Monopoly and Minecraft, on the other hand, have different goals than these three games. In Monopoly, players strive to keep their financial assets and not to go bankrupt. In contrast, Minecraft has no clear goals because the game is endless, but players can restructure and protect their realm as they wish.

In some of the preferred games, such as football, basketball, and volleyball, the player is engaged in the game with a team. When teams work towards a goal, individual performances increase as the cognitive load on each individual is reduced (Şahin, 2015). To compare games further, in Monopoly, the player is represented by a pawn in the game, whereas in Minecraft a digital avatar serves this function. An avatar is a medium of the self that represents the user in an environment (Lin \&Wang, 2014; Ratan \& Sah, 2015; Tavinor, 2017; Tysen, Hitchens \& Brolund, 2008). In games, physical material like pawns or digital images such as an avatar may be used to represent the player. When avatars are designed in an authentic way that matches the content and the target audience of the game, they can contribute to the desired change in attitudes and behavior (Shaw, Kenski, Stromer-Galley, Martney, Clegg, Lewis, Folkestas \& Strzalkowski, 2016). Also, the pace of behavior change is likely to increase when the player finds an avatar with which they can identify (Cohen, 2001; Klimmt, Hefner, Vardere, Roth \& Blake, 2010). To this point, it is useful to provide users with the opportunity to choose between several avatars, as in Minecraft, or with access to customizing their own avatar.

Another similarity between the preferred games identified in this study is that these games allow users to communicate and interact with each other as they play. Most of these games require at least two players to play. Hence this feature allows for socialization in addition to providing an entertaining experience. The fact that many games share this feature indicates that the opportunity to socialize is an important contributing factor to the popularity of a game. This result also supports the suggestion that people not only look for ways to have fun or spend quality time but also for social interaction when they engage in gameplay (Lazzaro, 2004). Thus, providing opportunities in the game for individuals to socialize is crucial if a game design is to reach large masses.

The design of Minecraft, one of the students' top preferences, is distinguished from the other games in many ways. The most important aspect in this case is that players need technology for playing the game. Minecraft is a sandbox game which can be played via a computer or a tablet and does not provide any feedback regarding scores, penalties, wins, or losses. The game can be played individually or with a group of friends. Lastly, the educational version of Minecraft can be integrated directly into the design of learning environments, in contrast to all the other games that were strongly preferred.

In summary, the results obtained in the scope of this study show that individuals' expectations of games are not limited to entertainment. The survey responses revealed that participants are more likely to prefer games which allow socialization and contribute to their cognitive development. Thus, game designers must aim to design rich game experiences which provide skill-building opportunities to the individual, rather than just giving them a chance to have fun. Furthermore, the games preferred by participants were found to feature similar game mechanics, which can be interpreted as an indication that game mechanics is the aspect with the most powerful impact on individuals' game preferences. Given this information, choosing game mechanics that are fun and have skill-building qualities may be one of the keys of game design. Lastly, some game mechanics must be integrated into the design, as suggested in the literature, in order to create a rich game experience. 
The participant responses point to the possibility that the lack of clear and specific end goals, as in Minecraft, can make the game as attractive as games with specific end goals. If the design is to be based on an ultimate goal, the principle of small steps defined in the full learning model must be followed (Bloom, 1984). In addition, as Vygotsky indicates in his Cognitive Learning Theory, the learning task should be breaking down into phases or the difficulty level should be tailored to the student's performance (Simoes, Redondo \& Villas, 2013). In the educational game design process, it is recommended that players be able to receive instant feedback, follow various paths to a solution, learn from their own mistakes through trial and error, cooperate and compete with each other, and that the game should follow a plot or a storyline (Simoes et al., 2013). A well-designed game is expected to be congruent with the context, society, and culture in which it is presented (Zhu, Yu \& Riezebos, 2016). In the process of designing an entertaining learning environment, the recommendations found in the literature must be followed.

Technology has always been a trigger for better and more efficient learning environment design in the field of education. In this process, the choice of technologies to be integrated into the learning environment changes with respect to the dominant paradigm (Almedia \& Simoes, 2019). In the past quarter of a century, with the advent of new technologies and the changing needs of the world, there have been four main paradigms dominating the field of education (Bartolome, Castaneda \& Adel, 2018). The first of these, education 1.0, is the main descriptive model. Education 2.0 calls for teaching through project-based learning, group work, and learning environment design without oral or written assessments. Students are active participants in the learning process in education 3.0, where student creativity is key for real life situations placed in the learning environment. Lastly, education 4.0 aims to provide flexible and personalized learning environments which adapt to the needs and pace of students (Bartolome, Castaneda \& Adel, 2018). Where a certain paradigm prevails, i.e. education 3.0, a certain technology is also commonplace - Ardunios, in this case. Today with the emergence of education 4.0, artificial intelligence, augmented reality, virtual reality, and the internet of things are presumably the matching technologies that will become integral parts of learning environments (Shahroom \& Hussin, 2018). Especially considering that these technologies are used in games today, it appears as though learning environments will continue to be enriched with games in the coming period. In addition, education 4.0 learning environments have to contribute to the process of students being creative individuals. Therefore, it is now very important that learning environments allow them to design their own games. In light of this and the findings of this study, the steps to be followed regarding the design of a game-based learning environment can be summarized as follows:

Decisions should be taken in the design process based on both game design and educational science theories (Dodlinger, 2007; Kiili, 2005).

Players should be given the opportunity to control the game and design should be made according to their preferences (Annetta, 20).

Participants must be able to follow more than one trajectory for solving problems.

Feedback must be quick and timely.

The game experience must be enhanced with the use of multiple game mechanics which are entertaining.

When setting goals, in a case where there is a single ultimate goal, the goal must be broken down into phases appearing in order of difficulty, from easy to difficult.

A configurable system must be designed based on the individual's pace of learning or progress.

Individuals must be allowed to learn from their own mistakes through trial and error.

The design must revolve around a plot or a storyline. 


\section{REFERENCES}

Agrawal, R., Imieliński, T., \& Swami, A. (1993). Mining association rules between sets of items in large databases. Acm Sigmod Record, 22(2), 207-216.

Akpınar, H. (2000). Veri tabanlarında bilgi keşfi ve veri madenciliği. İstanbul Üniversitesi Isşletme Fakültesi Dergisi, 29(1), 1-22.

Almedia, F. \& Simoes, J. (2019). The role of serious games, gamification and industry 4.0 tools in the education 4.0 pardigm. Contemporary Educational Technology, 10(2), 120-136.

Amory, A. (2007). Game object model version II: a theoretical framework for educational game development. Educational Technology Research and Development, 55(1), 51-77.

Amory, A., \& Seagram, R. (2003). Educational game models: Conceptualization and evaluation. South African Journal of Higher Education, 17(2), 206-217.

Annetta, L. A. (2010). The "I's" have it: A framework for serious educational game design. Review of General Psychology, 14(2), 105-113.

Ayan, S. (2013). Games and sports preferences of children. Educational Research and Reviews, 8(8), 396404.

Bartolome, A., Castaneda, L. \& Adell, J. (2018). Personalisation in educational technology: The absence of underlying pedagogies. International Journal of Educational Technology in Higher Education, 15(14), 1-17.

Barzilai, S., \& Blau, I. (2014). Scaffolding game-based learning: Impact on learning achievements, perceived learning, and game experiences. Computers \& Education, 70, 65-79.

Bloom, B. S. (1984). The 2-sigma problem: The search for methods of group instruction as effective as oneto-one tutoring. Educational Researcher, 13(6), 4-16.

Bulut, D. (2015). Eğitsel oyun tasarlama sürecinin öğrencilerin yaratıcllklarına etkisi, (Master Thesis). Bahçeşehir Üniversitesi Eğitim Bilimleri Enstitüsü, İstanbul.

Burguillo, J. C. (2010). Using game theory and competition-based learning to stimulate student motivation and performance. Computers \& Education, 55(2), 566-575.

Cohen, J. (2001). Defining identification: A theoretical look at the identification of audiences with media characters. Mass Communication \& Society, 4(3), 245-264.

Cornett, S. 2004. The usability of massively multiplayer online roleplaying games: Designing for new users. In Proceedings of the 2004 Conference on Human Factors in Computing Systems. ACM Press, New York, 703-710.

Crawford, C. (1984). The art of computer game design. New York: McGraw-Hill/Osborne Media.

Crawford, G., \& Gosling, V. (2005). Toys for boys? Women's marginalization and participation as digital gamers. Sociological Research Online, 10(1), 1-11.

Doğan, B. (2008). Bankaların Gözetiminde bir araç olarak kümeleme analizi: Türk bankacıllk sektörü için bir uygulama, (PhD Dissertation). Kadir Has University, İstanbul.

Dondlinger, M. J. (2007). Educational video game design: A review of the literature. Journal of Applied Educational Technology, 4(1), 21-31.

Durdu, P. O., Hotomaroğlu, A., \& Çağıltay, K. (2004). Türkiye'deki öğrencilerin bilgisayar oyunu oynama alışkanlıkları ve oyun tercihleri: ODTÜ ve Gazi ünivesitesi öğrencileri arası bir karşılaştırma. Proceeding of Bilişim Teknolojileri Işı̆̆ında Eğitim Konferansı, Ankara.

Eglesz, D., Fekete, I., Kiss, O. E., \& Izso, L. (2005). Computer games are fun? On professional games and players' motivations. Educational Media International, 42(2), 117-124.

Ergün, E. (2008). Ürün kategorileri arasındaki satış iliş̧isinin birliktelik kuralları ve kümeleme analizi ile belirlenmesi ve perakende sektöründe bir uygulama (Phd Dissertation). Afyon Kocatepe University, Afyon.

Erhel, S., \& Jamet, E. (2013). Digital game-based learning: Impact of instructions and feedback on motivation and learning effectiveness. Computers \& Education, 67, 156-167.

Faisal, A., \& Peltoniemi, M. (2018). Establishing video game genres using data-driven modeling and product databases. Games and Culture, 13(1), 20-43.

García, E., Romero, C., Ventura, S., Castro, C., \& Calders, T. (2010). Association rule mining in learning management systems. V. Kumar (Ed.). Handbook of Educational Data Mining. (pp. 93-106). Newyork: Taylor \& Francis Group.

Giammarco, E. A., Schneider, T. J., Carswell, J. J., \& Knipe, W. S. (2015). Video game preferences and their relation to career interests. Personality and Individual Differences, 73, 98-104.

Griffiths, M. D., Davies, M. N., \& Chappell, D. (2004). Online computer gaming: a comparison of adolescent and adult gamers. Journal of Adolescence, 27(1), 87-96. 
Herodotou, C., Kambouri, M., \& Winters, N. (2011). The role of trait emotional intelligence in gamers' preferences for play and frequency of gaming. Computers in Human Behavior, 27(5), 1815-1819.

Huizinga, J. (1955). Homo Ludens: A study of the play element in culture. Boston: Beacon Press.

Horzum, M. B. (2011). İlköğretim öğrencilerinin bilgisayar oyunu bağımlılık düzeylerinin çeşitli değişkenlere göre incelenmesi. Eğitim ve Bilim, 36(159), 56-68.

Joffe, H. (2012). Thematic analysis. Qualitative research methods in mental health and psychotherapy, D. Harperi A. Thompson (Ed.) In Qualitative Research Methods in Mental Health and Psychotherapy: A Guide for Students and Practitioners (pp. 209-223). Chichester: Wiley-Blackwell.

Kaplan Akilli, G. \& Çağıltay, K. (2006). An instructional Ddsign/development model for the creation of gamelike learning environments: The FIDGE Model. Proceeding of Affective and Emotional Aspects of Human-Computer Interaction (pp. 93-112). Amsterdam, Holland.

Kerlinger, F. N. (1973) Foundation of behavioural research, (Second Edition), Holt, Rinehart and Winston, Inc.

Kort-Butler, L. A. (2020). Gamers on gaming: a research note comparing behaviors and beliefs of gamers, video game players, and non-players. Sociological Inquiry, 1-21.

Kiili, K. (2005). Digital game-based learning: Towards an experiential gaming model. The Internet and Higher Education, 8(1), 13-24.

Klimmt, C., Hefner, D., Vorderer, P., Roth, C., \& Blake, C. (2010). Identification with video game characters as automatic ahift of self-perceptions. Media Psychology, 323-338.

Lazzaro, N. (2004). Why we play games: Four keys to more emotion without story. . XEOX Design, Ink.

Lee, D., \& LaRose, R. (2007). A socio-cognitive model of video game usage. Journal of Broadcasting \& Electronic Media, 51(4), 632-650.

Liao, G. Y., Tseng, F. C., Cheng, T. C. E., \& Teng, C. I. (2020). Impact of gaming habits on motivation to attain gaming goals, perceived price fairness, and online gamer loyalty: Perspective of consistency principle. Telematics and Informatics, 49, 101367

Lin, H., \& Wang, H. (2014). Avatar creation in virtual worlds: Behaviors and motivations. Computers in Human Behavior, 34, 213-218.

Lucas, K., \& Sherry, J. L. (2004). Sex differences in video game play: A communication-based explanation. Communication Research, 31(5), 499-523.

Manero, B., Torrente, J., Freire, M., \& Fernández-Manjón, B. (2016). An instrument to build a gamer clustering framework according to gaming preferences and habits. Computers in Human Behavior, 62, 353-363

Merceron, A., Yacef, K., Romero, C., Ventura, S., \& Pechenizkiy, M. (2010). Measuring correlation of strong symmetric association rules in educational data. V. Kumar (Ed.). Handbook of Educational Data Mining, 245-256.

Miles, M. B., \& Huberman, A. M. (1994). Qualitative data analysis: An expanded sourcebook. Sage.

Moreno-Ger, P., Burgos, D., Martínez-Ortiz, I., Sierra, J. L., \& Fernández-Manjón, B. (2008). Educational game design for online education. Computers in Human Behavior, 24(6), 2530-2540.

Özçalıcı, M. (2017). Veri madenciliğinde birliktelik kuralları ve ikinci el otomobil piyasası üzerine bir uygulama. Ordu Üniversitesi Sosyal Bilimler Araştırma Dergisi, 7(1), 45-58.

Pala F. K., \& Erdem, M. (2011). Dijital oyun tercihi ve oyun tercih nedeni ile cinsiyet, sınıf düzeyi ve öğrenme stili arasındaki ilișkiler üzerine bir çalıșma. Ahi Evran Üniversitesi Kırșehir Eğitim Fakültesi Dergisi, 12(2), 53-71.

Palomba, A. (2019). Digital seasons: How time of the year may shift video game play habits. Entertainment Computing, 1-7.

Pachet, F. \& Addressi, A.R. (2004). Music: When children reflect on their own playing style: Experiments with continuator and children. Computers in Entertainment, 2(2), 1-19.

Prensky, M. (2001). Digital natives, digital immigrants' part 1. On the Horizon, 9(5), 1-6.

Quaiser-Pohl, C., Geiser, C., \& Lehmann, W. (2006). The relationship between computer-game preference, gender, and mental-rotation ability. Personality and Individual Differences, 40(3), 609-619.

Ratan, R., \& Sah, Y. J. (2015). Leveling up on stereotype threat: The role of avatar customization and avatar embodiment. Computers in Human Behavior, 50, 367-374.

Rüppel, U., \& Schatz, K. (2011). Designing a BIM-based serious game for fire safety evacuation simulations. Advanced Engineering Informatics, 25(4), 600-611.

Roodt, S., \& Saunders, B. (2017). Digital game-based learning for the next generation: perceptions of university students. Proceedings of EDULEARN17 Conference, 3-4 April 2017, Spain.

Ryan, R. M., Rigby, C. S., \& Przybylski, A. (2006). The motivational pull of video games: A self-determination theory approach. Motivation and Emotion, 30(4), 344-360. 
Shahroom, A., \& Hussin, N. (2018). Industrial revolution 4.0 and education. International Journal of Academic Research in Business and Social Sciences, 8(9), 314-319.

Scharkow, M., Festl, R., Vogelgesang, J., \& Quandt, T. (2015). Beyond the "core-gamer": Genre preferences and gratifications in computer games. Computers in Human Behavior, 44, 293-298.

Shaw, A., Kenski, K., Stromer-Galley, J., Mikeal Martey, R., Clegg, B. A., Lewis, J.E., Folkestad, J. E., \& Strzalkowski, T. (2016). Serious efforts at bias reduction:The effects of digital games and avatar customization on three cognitive biases. Journal of Media Psychology: Theories, Methods, and Aplications, 30(1), 16-28.

Simoes, J., Redondo, R. \& Vilas, A. (2013). A Social gamification framework for a k-6 learning platform. Computers Game Technology, 29(2), 345-353.

Song, M. and S. Zhang (2008). EFM: A model for educational game design, S. Link (Ed.), Lecture Notes in Computer Science, Springer US. 509-517.

Staalduinen, J. P. V., \& Freitas, S. D. (2011). A game-based learning framework: Linking game design and learning outcome. M. S. Khine (Ed.). Learning to Play: Exploring the Future Of Education With Video Games (pp. 29- 40). Peter Lang.

Stavropoulos, V., Rennie, J., Morcos, M., Gomez, R., \& Griffiths, M. D. (2020). Understanding the relationship between the Proteus effect, immersion, and gender among World of Warcraft players: An empirical survey study. Behaviour \& Information Technology, 1-16.

Sung, H. Y., \& Hwang, G. J. (2013). A collaborative game-based learning approach to improving students' learning performance in science courses. Computers \& education, 63, 43-51.

Sweetser, P., \& Wyeth, P. (2005). GameFlow: a model for evaluating player enjoyment in games. Computers in Entertainment (CIE), 3(3), 1-24.

Şahin, M. (2015). Oyunlaştırılmış oyun temelli öğrenmenin öğrencilerin fen bilimleri dersi başarılarına ve derse yönelik tutumları etkisi (Master Thesis), Bahçeşehir Üniversite, İstanbul.

Tatli, Z. (2018). Traditional and digital game preferences of children: A CHAID analysis on middle school students. Contemporary Educational Technology, 9(1), 90-110.

Tavinor, G. (2017). What's my motivation? video games and interpretativeperformance, The Journal of Aesthetics and Art Criticism, 75(1), 23-33.

Trefry, G. (2010). Casual game design: Designing play for the gamer in all of us. Florida: CRC Press

Tsai, M. J., Huang, L. J., Hou, H. T., Hsu, C. Y., \& Chiou, G. L. (2016). Visual behavior, flow and achievement in game-based learning. Computers \& Education, 98, 115-129.

Tüzün, H., Yılmaz-Soylu, M., Karakuş, T., İnal, Y., \& Kızılkaya, G. (2009). The effects of computer games on primary school students' achievement and motivation in geography learning. Computers \& Education, 52(1), 68-77.

Tychsen, A., Hitchens, M., \& Brolund, T. (2008), Character play - the use of gamecharacters in multi-player role-playing games across platform. ACM Computers Entertainment, 6, 1-24.

Wang, Z., Sapienza, A., Culotta, A., \& Ferrara, E. (2019, August). Personality and behavior in role-based online games. In 2019 IEEE Conference on Games (CoG) (pp. 1-8). IEEE.

Wasserman, J. A., \& Rittenour, C. E. (2019). Who wants to play? Cueing perceived sex-based stereotypes of games. Computers in Human Behavior, 91, 252-262

Wu, J. H., Wang, S. C., \& Tsai, H. H. (2010). Falling in love with online games: The uses and gratifications perspective. Computers in Human Behavior, 26(6), 1862-1871.

Van Eck, R. (2006). Digital game-based learning: It's not just the digital natives who are Restle1ss. EDUCAUSE Review, 41(2), 1-16.

Zhu, Z., Yu, M. \& Riezebos, P. (2016). A research framework of smart education. Smart Learning Environments, 3(1), 1-17.

Zin, N.A.M., Jaafar, A., \& Yue, W.S. (2009). Digital game-based learning (DGBL) model and development methodology for teaching history. WSEAS Transactions on Computers, 8(2), 322-333. 